The University of Southern Mississippi The Aquila Digital Community

Faculty Publications

Spring 3-1-2001

\title{
Conversations in Cold Rooms: Women, Work and Poverty in Nineteenth-Century Northumberland
}

L. Margarett Barnett

University of Southern Mississippi

Follow this and additional works at: https://aquila.usm.edu/fac_pubs

Part of the History Commons

\section{Recommended Citation}

Barnett, L. M. (2001). Conversations in Cold Rooms: Women, Work and Poverty in Nineteenth-Century Northumberland. Albion, 33(1), 149-150.

Available at: https://aquila.usm.edu/fac_pubs/3940

This Book Review is brought to you for free and open access by The Aquila Digital Community. It has been accepted for inclusion in Faculty Publications by an authorized administrator of The Aquila Digital Community. For more information, please contact Joshua.Cromwell@usm.edu. 
Jane Long. Conversations in Cold Rooms: Women, Work and Poverty in NineteenthCentury Northumberland. Woodbridge, Suffolk: The Boydell Press, 1999. Pp. xii, 241. \$75.00. ISBN 0-86193-240-4.

The author begins the work with a quotation from The Mill on the Floss that explains her title. Poverty, said George Eliot, exerts a chilling effect on social interaction similar to that of a cold room, causing people to retreat in discomfort and rendering conversation with those in its grip unthinkable. The poor, Long notes, their opinions unsought by others and their own written accounts sparse, become mute players on the world's stage, largely excluded from contemporary records and so from future history books. While historians have made great strides in recent decades in reconstructing the lives of the most silent group of allpoor women-there remain gaps in the historical literature. Observing that "the rooms of working women and poor women in nineteenth-century Northumberland seem cold indeed, rarely visited, distant, and quiet" (p. 4), Jane Long proposed to close one of those gaps with this book. She looks first at the social constraints that affected the type of work women in general performed in this period and that limited the ability to earn a decent wage. Earlier feminist historians have made familiar themes of such factors as the traditional gender division of labor, the lower monetary value assigned to women's work, and the negative effect of expanding Victorian middle-class standards of femininity. Long provides no new insights, but she does draw fruitfully on local history for examples. Unfortunately, this section of the book is particularly marred by the jargon and poor writing that often obscures the author's meaning throughout. Although the title of the book suggests broader coverage, Long discusses in detail just two regional female occupations-work in the white lead industry that was centered in Newcastle, and bondaging, a type of farm employment that was once practiced throughout Northumberland and other parts of the north. Both jobs were unusual in that they paid exceptionally good wages for unskilled work, enabling women to support themselves and, in the case of lead workers, even families. Both involved heavy manual labor in harsh, injurious surroundings, however, and over time both became considered unsuitable for women. Predominantly young and single in an area short of men, the bondager assumed a man's job and led a hard and migratory existence. Lead handling, a task males in the industry left to women, often caused sickness and death. Female lead workers told government investigators that they undertook such dangerous employment only because they could not otherwise earn enough to live on. So did the disappearance of these occupations around the turn of the century represent an end to the exploitation of vulnerable individuals lacking other options or was it a case of (male) society forcing women out of "unfeminine" high-paying work and confining them to their proper, dependent, sphere? Declaring in the chapter on lead workers that "the example of Newcastle illustrates clearly that women's bodies, and their poverty, were indeed linked to specific and general disorder, and fear of invasion" (p.77), Long settles for the latter. Her chapter on bondagers is mercifully free from such language and forms by far the most interesting and original part of the book, providing a poignant reminder of these staunchly independent souls, who, as far as historians can tell, left no personal chronicles of their own. A late photograph showing a small group of bondagers dressed in their distinctive clothing is included in the text. The final third of the volume consists of the assessment of poor relief and philanthropy in the region, as these applied to women. Charitable donations in the Newcastle area far outstripped official funding, Long writes, making philanthropy in particular a fertile field for historical research. Descriptions of the Charity Organization's Society's activities and of life at various 


\section{Albion}

private refuges for "fallen" women, such as the off-putting and short-lived Brandling Place Home for Penitent Women, provide some interesting reading. The Salvation Army's Rescue Homes, whose local records are unusually extensive, provided the author with her most compelling material, however. Long found hundreds of statements by applicants for aid that allowed individual, and identified, poor women to speak for themselves in her text, explaining the reasons for their economic circumstances and challenging contemporary definitions of moral behavior. Overall, this book is uneven in quality and strikes one as more a collection of essays on related subjects than a comprehensive treatment of a single theme. If not well-presented, the data is nevertheless extremely well-researched. The author has made excellent use of regional archives, reports, and local publications and has examined an equally impressive array of secondary literature. Despite its flaws, the book contributes on several levels to ongoing efforts to bring past generations of working women "in from the cold."

University of Southern Mississippi

L. MARGARET BARNETT

S. C. Williams. Religious Belief and Popular Culture in Southwark c.1880-1939. (Oxford Historical Monographs.) New York: Oxford University Press. 1999. Pp. xii, 206. \$70.00. ISBN 0-19-820769-7.

This book is a fascinating local study and an important contribution to a continuing debate about whether the urbanization of Britain in the nineteenth century meant secularization, especially of the new urban working class. The argument for secularization, advanced over some decades by K. S. Inglis and Alan Gilbert, was based on the statistics of actual church-going and on the disappointed expectations of churchmen themselves. It is a picture that has been challenged by scholars like Hugh McLeod and Callum Brown on two levels. First, there was more working-class formal religion and proletarian participation in religious institutions than was previously thought; but second, there was a great deal of informal and popular religion that excluded regular church attendance, but is to be understood sympathetically on its own terms, as the belief system of men and women who, whatever their practice, regarded themselves as Christians.

Williams sees the popular culture of Southwark between 1880 and 1939 as possessing a unity involving the sense of neighborhood pervading the collection of village communities that survived into modern south London. Her argument is a subtle one, based upon an extensive body of oral evidence, skillfully collected, upon the Edward Lovett collection of local folklore, and working-class autobiographies, as well as more conventional historical source material, that the official religion of the Churches made an important contribution to the values of the urban poor, and that their belief and practice are not to be divided between unofficial and official religion, but had a unified character all their own. Thus, the book refreshingly suggests that popular religion is to be taken as a whole, and is not to be dismissed, as have many past churchmen and contemporary historians, as largely a vestigial belief in magic or as a species of neo-paganism. Church attendances for the rites of passage, baptisms, churchings after childbirth, weddings, and funerals, and for Harvest Festivals and New Year watch night services, were popular, sometimes increasingly so, and were regarded as bringing good luck, like amulets and charms, yet they were also seen as a part of duty and thanksgiving to the Christian God. Though there was little sense of sin, other aspects of Christianity were overwhelmingly popular: mothers' meetings, Sunday School attendance 